\title{
Dubai and United Arab Emirates Ministry of Happiness: Presentation of the National Happiness and Positivity Programme - Qualitative Analysis
}

\author{
Diamantino Ribeiro \\ CEFAGE and Universidade de Évora, Portugal \\ António Pedro Costa \\ CIDTFF of Aveiro University, Portugal \\ Jorge Remondes
}

CETRAD - The Centre for Transdisciplinary Development Studies, Portugal

\begin{abstract}
Scientific research on the question of how happiness can be increased and then sustained has still a long way ahead. The authors have been developing studies in this field and have chosen the happiness initiatives of the Dubai and UAE government to elaborate a case study. This paper, extracted from the wider investigation, presents a study based on government communication on the creation of the Dubai and United Arab Emirates Ministry of Happiness. In the scope of this work we have chosen the National Happiness and Positivity Programme of the Dubai and United Arab Emirates Ministry of Happiness. Using the technique of content analysis, through the use of webQDA software, the aim was to understand how the government communicated its strategy for happiness and which are the most used concepts to capture the attention of institutions and citizens. Consequently, the aim was to understand what actions the government has advocated to implement the said programme. The results imply that the concept of positivity has a focus that is very close and complementary to that of happiness. It is also inferred that the government intends to promote 'happiness as a way of life', and also to involve the private sector in the National Happiness and Positivity Programme. Finally, the author's contribution to this research field is to demonstrate that this model of positivity and sustainable happiness can be extensively implemented, including in the academy.
\end{abstract}

Keywords: happiness, content analysis, government communication, ministry of happiness

\section{Introduction}

Communication is an important element in the material of influence which leads to innovation and modernization of a society (Kanozia, 2016). The study of government communication, in the logic of communication for development, is an academically challenging area due to the constant updating of research content and the thematic scope, diversity, typology, 
implications (positive or negative) of government policies, among other aspects. The beginning of the study that underlies this work coincided with the initiative of the governing authorities of the United Arab Emirates to create the Ministry of Happiness in the year 2016 (D. J. T. Ribeiro, Remondes, \& Costa, 2017).

It was understood that there could be academic and social interest in deepening the study of communication carried out by the Ministry of Happiness and in understanding its contribution to development. At the same time, it was considered interesting to understand the objectives of the creation of this Ministry, the communication model used by the UAE government and how an abstract concept such as Happiness is translated into concrete actions that can effectively contribute to happiness and the well-being of citizens and to development (D. J. T. Ribeiro, Remondes, \& Costa, 2019b).

The investigation begins by analysing government communication within the general communication framework, communication theories and the mainstream media today, followed by a case study through content analysis of the news released by the governments of Dubai and the United Arab Emirates in one year (February 2016 to February 2017), specifically about the Ministry of Happiness (D. J. T. Ribeiro, Remondes, \& Costa, 2019c).

Soon after the creation of the Ministry of Happiness (February 2016), it was possible to gather news in international media related to the objectives that were the basis of the creation of this government body (D. J. T. Ribeiro, Remondes, \& Costa, 2019a).

The option to select a time period of 1 year, in addition to the analysis of the communication, allowed for the understanding of the evolution of communication and the use of human and material resources.

Following a qualitative approach, the content of this news was analysed through the qualitative analysis software webQDA (Costa, de Souza, Moreira, \& de Souza, 2018). In this article, the content of one of the most emblematic texts was analysed in the scope of the research carried out, which concerns the launching of the National Happiness Programme.

In the following sections we will have a brief view on government communication, on the Ministry of Happiness, methodology, analysis and discussion of results.

\section{Government Communication}

When one thinks of government communication, taking into account where its nomenclature directs us, one thinks of the exchange and sharing of information between the State and the people, the citizens.

This particular form of communication, in fact, is a legitimate way for a government to render accounts and bring the projects, actions, activities and policies that it performs, and which are of public interest, to the knowledge of the public (Brandão, 2009). Brandão (2009) argues that government communication can be understood as a form of public communication. These two forms of communication share some resemblances, because government communication aims to be an instrument for building the public agenda, as well as a mechanism of accountability and a stimulus for social participation.

The duty of government communication is to inform citizens of what is happening within the government and, for this reason, it is an instrument that allows them to learn about 
government actions and, simultaneously, that they can convey their expectations to the government (Torquato, 1985).

It is necessary that government communication be guided by some standards and rules, so as to fulfil its duty - to inform society - because the communication system is essential for the processing of the internal administrative functions and for the relationship with the external environment (Kunsch, 2003). Since government communication is not an easy process, the government must make an effort to improve its communication, making it understandable and accessible to all. In this sense, organisations have to be convinced that communication needs to be worked on and managed by specialised professionals. Otherwise, they will always be improvising, thinking that they are communicating when they are merely reporting. You cannot plan organisational communication without basic foundations (Kunsch, 2003).

From a strategic point of view, government communication should be planned for its target audience, studies should be made to assess the image of the administration with the public and events should be planned to disseminate the information. Assuming that there is political will and a decision by senior managers to develop a communication plan, the planning process should be organised into three phases: strategic diagnosis, strategic planning and strategic management (Kunsch, 2003).

In short, government communication should be transparent, be well acquainted with its interlocutors and be carried out on the basis of defined theoretical principles, supported by good planning.

\section{The Ministry of Happiness}

The science of happiness looks at "what makes happy people happy" (Lyubomirsky, Sheldon, \& Schkade, 2005) but the subjective nature of happiness makes it incredibly difficult to define and also challenging to measure (Kringelbach \& Berridge, 2010). However, happiness can be thought of as experiencing predominantly positive emotions, or affective states, rather than negative ones (Tkach \& Lyubomirsky, 2006). So, positive emotions can be a sign of happiness (Fredrickson, 2001). (Seligman, 2011), credited as being the 'father of Positive Psychology', suggests that there are three kinds of happiness: 1 . pleasure and gratification; 2 . embodiment of strengths and virtues; 3. meaning and purpose Seligman (2011) presented a model for positivity/psychological wellbeing, known as PERMA model that comprehends five domains: Positive emotions - P Engagement - E; Relationships - R; Meaning - M; Accomplishment - A.

(Lyubomirsky et al., 2005) supported on the past well-being literature propose that a person's chronic happiness level is governed by 3 major factors: a genetically determined set point for happiness, happiness-relevant circumstantial factors, and happiness-relevant activities and practices. The authors then consider adaptation and dynamic processes to show why the activity category offers the best opportunities for sustainably increasing happiness.

So, in the pursuit of sustainable happiness of the Kingdom of Dubai and of the United Arab Emirates, Sheikh Mohammed bin Rashid Al Maktoum ${ }^{1}$ launched in 2014 the Happiness Index to measure how satisfied citizens are with government services. In the start of 2016, $\mathrm{HH}$ surprised the media, via Twitter, with the indication that he would appoint a Minister of

\footnotetext{
${ }^{1}$ Retrieved from: https://www.khaleejtimes.com/nation/government/shaikh-mohammed-launches-happinessindex. Last accessed on 09-02-2018
} 
Happiness. Days later, he appointed Mrs Ohood Al Roumi ${ }^{1}$ to take the position of Minister of State for Happiness as an integral part of the Governor's office and whose main mission would be to oversee "plans, projects, programmes and indices" that would improve the overall climate of the country.

At the inauguration, the Minister stated that the purpose of her work was to create authentic and genuine Happiness in public services. A little more than a month after taking office, the Minister presented a package of positive initiatives and institutional happiness in the Federal government. The National Plan for Happiness and Positivity (PNF) was approved on International Happiness Day on 21 March. The PNF comprises 3 main areas:

Inclusion of happiness in the policies, programmes and services of all government agencies as well as in the work environment.

Consolidation of values of positivity and happiness as a way of life in the UAE community.

Development of tools and indices to measure happiness levels.

The programme is based on a scorecard ${ }^{2}$ of happiness and positivity, and all national government agencies will have to work according to this instrument. The government approved programme also includes:

The appointment of a CEO for happiness and positivity in all government agencies.

The establishment of happiness and positivity boards in federal entities.

Certain hours allocated to programmes and activities related to happiness in the Federal government.

Creation of offices of happiness and positivity.

Customer service centres will be transformed into customer happiness centres.

Special programmes are tailored to change the culture of government employees, to serve the clients and make them happy.

The programme also includes annual indices, surveys and reports to measure happiness in all sectors of the community.

Since the approval of the Programme, the government, and in particular the Minister, have been involved in initiatives ranging from the scientific training of managers specialised in happiness to the integration of women and children into actions aimed at promoting happiness and positivity. Meanwhile, the programme has been extended to the private sector and has attracted the support of the country's large economic groups.

One of the concerns of the government and the Minister is the measurement of results, with the aim of bringing policies closer to the real desire of citizens. This measurement includes, among other tools, a scientific study that is being carried out by the University of Abu Dhabi, based on citizens' tweets in the year 2015. In concrete terms, the government has

\footnotetext{
${ }^{1}$ Retrieved from: https://www.happy.ae/en. Last accessed on 09-02-2018

2 Definition: 'a report or indication of the status, condition, or success of something or someone'. Retrieved from https://www.merriam-webster.com/dictionary/scorecard. Last accessed on 09-02-2018
} 
endeavoured to make the most of its adherence to the concept created in the 1970s in the Kingdom of Bhutan (D. J. T. Ribeiro, Laranjeira, \& Remondes, 2019). To do this, it has changed the name of public services (the citizen's bureau was named the Happiness Centre), amusement parks and sports and, for example, the new area of the city that is being built next to the future airport of Dubai (e.g. Dubai World) will be named the City of Happiness. In addition, it has encouraged several organisations to launch initiatives for the happiness of their workers, as in the case of "Dubai Culture", which implemented the "Make It Happen" programme. It believes that happy workers are contagious to customers and also wants private companies to work to make customers happy.

Overall, the government believes that the model can be replicated internationally. It promotes the constant collection of opinions from the public and from experts. In this context, an international event was held in 2017 called "Global Dialogue for Happiness", on the eve of one of the biggest political events of the year in the region, the World Government Summit. The "Global Dialogue for Happiness" was attended by more than 30 experts (scientists, economists, governors, psychologists, etc.) with the responsibility of exchanging ideas and encouraging discussion about trends and happiness for the people of the world. The two events had a new edition, in February 2018. During the 2018 "World Happiness Forum", the first Global Happiness Policy Report was launched.

\section{Methodology}

In this study, the work was structured as recorded in the following diagram (Figure 1) as a way to obtain the data to be analysed:

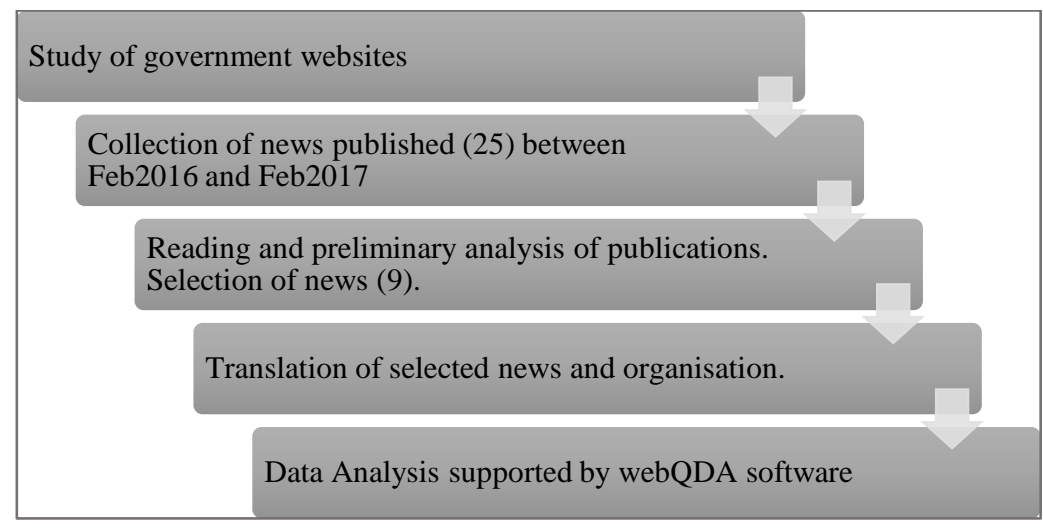

Figure 1 - Evolution and structure

The news was collected for the analysis of content published in the media during the period of analysis (February 2016 to February 2017) in order to understand the evolution of the concept, the form and direction of communication, and actions on the ground of the UAE government. Table 1 summarises the dates, sources and titles related to the texts selected for analysis.

Table 1 - Listing of texts in chronological order

\begin{tabular}{l|l|l|l} 
\# & Date & Title & Power
\end{tabular}




\begin{tabular}{|l|l|l|l|}
\hline $\mathbf{1}$ & February 8, 2016 & $\begin{array}{l}\text { "Genuine happiness is the ambition of } \\
\text { the United Arab Emirates Minister of } \\
\text { Happiness" }\end{array}$ & Gulf News \\
\hline $\mathbf{2}$ & March 7, 2016 & $\begin{array}{l}\text { "Mohammed analyses the UAE } \\
\text { Happiness and Positivity Programme" }\end{array}$ & $\begin{array}{l}\text { Emirates 24/7 } \\
\text { News }\end{array}$ \\
\hline $\mathbf{3}$ & March 21, 2016 & $\begin{array}{l}\text { "United Arab Emirates Happiness } \\
\text { Programme approved on International } \\
\text { Day of Happiness" }\end{array}$ & $\begin{array}{l}\text { Emirates 24/7 } \\
\text { News }\end{array}$ \\
\hline 4 & May 15, 2016 & $\begin{array}{l}\text { "Happiness, positivity through the eyes } \\
\text { of children of the UAE - Children will } \\
\text { inspire the logo of the Happiness and } \\
\text { Positivity programme" }\end{array}$ & $\begin{array}{l}\text { Emirates 24/7 } \\
\text { News }\end{array}$ \\
\hline $\mathbf{5}$ & June 14, 2016 & $\begin{array}{l}\text { "UAE reveal the formula for } \\
\text { Happiness" }\end{array}$ & $\begin{array}{l}\text { Emirates 24/7 } \\
\text { News }\end{array}$ \\
\hline 6 & June 30, 2016 & $\begin{array}{l}\text { "Joyful task for 60 Emirati named } \\
\text { pioneers of positive thinking in the } \\
\text { government" }\end{array}$ & $\begin{array}{l}\text { The National } \\
\text { UAE }\end{array}$ \\
\hline 7 & $\begin{array}{l}\text { September 1, } \\
2016\end{array}$ & $\begin{array}{l}\text { "Abu Dhabi teachers study Tweets to } \\
\text { assess Happiness in the UAE" }\end{array}$ & $\begin{array}{l}\text { The National } \\
\text { UAE }\end{array}$ \\
\hline 8 & Fecember 26, & $\begin{array}{l}\text { "The Crown Prince of Dubai welcomes } \\
\text { the Year of Donation" }\end{array}$ & $\begin{array}{l}\text { The National } \\
\text { UAE }\end{array}$ \\
\hline 9 & $\begin{array}{l}\text { "Dialogue on Happiness welcomes 300 } \\
\text { experts" }\end{array}$ & The Gulf Today \\
\hline
\end{tabular}

After a free translation into Portuguese (the native language of the authors), an analytical reading of the texts was carried out without any kind of formalities. Then the texts were imported to the webQDA platform. In a second reading, the contextualization was carried out and the categories adapted for each of the texts were created. Using the selection, collection and integration tool available in the software, the most representative contents of the communication were selected and integrated within the categories. At the same time, a cloud of the keywords of each of the texts was constructed. From the selections made, conclusions were drawn for each text. At the point of discussion of results, the link between all the texts is made and the conclusions drawn (D. Ribeiro, Costa, \& Remondes, 2020).

The analysed data were collected from the Internet or corpus latente - the corpus latente refers to the existence of large databases with which everyone can work, namely the Internet, which accumulates more and more information day after day in the form of texts, images and videos, among others (Pina, Neri de Souza, \& Leão, 2013). The corpus latente is a set of content, available on the Internet for those who wish, and have the necessary skills and qualifications, to extract them (Pina et al., 2013).

In order to analyse the data, the analysis of content was the recommended technique. Content analysis consists of a set of methodological tools that aims to analyse different sources of content, both verbal and nonverbal. With regard to its practical implementation, it covers several stages, particularly to confirm the full significance of the data collected. According to 
Costa and Amado (2018), these stages are, in turn, organised into seven distinct phases: 1. Definition of the problem, work objectives and theoretical basis; 2. Organization of the Data Corpus 3. Reading the Data 4. Categorization and Codification 5. Formulation of Questions 6. Analysis Matrices 7. Presentation of Results.

For Krippendorff (1990) content analysis is a research technique that allows one to make valid and replicable inferences of the data to its context. Hence, inferences are made about what can affect the type of interpretation of analysis, on the basis of establishing a relationship between the data obtained (Amado, Costa, \& Crusoé, 2017).

As support for the achievement of this establishment of relationship between data, technological tools can and should be used to obtain results that go beyond traditional observation/interpretation.

Bardin (2009) proceeds to a definition of codification, assigning it the meaning of transformation, especially through extraction, aggregation and enumeration, and based on certain precise rules on all the textual information, that end up representing all the characteristics of the content. Table 2 presents the proposal that was followed in this study.

Table 2 - Proposal of organisational model by Bardin (2009)

\begin{tabular}{|l|l|l|l|}
\hline Category & Subcategory & Registration Unit & Context Unit \\
\hline $\begin{array}{l}\text { Here the major } \\
\text { themes of the } \\
\text { analysed data are } \\
\text { joined together (in } \\
\text { this case the titles } \\
\text { of the texts). }\end{array}$ & $\begin{array}{l}\text { Most important } \\
\text { subtopics within a } \\
\text { certain major } \\
\text { theme. }\end{array}$ & $\begin{array}{l}\text { Fragments of text } \\
\text { taken by an } \\
\text { indication of a } \\
\text { characteristic } \\
\text { (category and and } \\
\text { subcategory). }\end{array}$ & $\begin{array}{l}\text { There } \\
\text { fragments of the } \\
\text { text } \\
\text { encompass the } \\
\text { registration unit, } \\
\text { contextualising the } \\
\text { registration unit. }\end{array}$ \\
\hline
\end{tabular}

The use of the webQDA tool to analyse the data of this study allowed the generation, as outputs, of tables (matrices) with the encoded data (Costa, Linhares, \& de Souza, 2014). On the other hand, according to Costa, Linhares and Souza (2014), Computer Assisted Qualitative Data Analysis Software (CAQDAS) extend the possibilities of communication among researchers in the definition of analysis (categorization, coding, and recoding, etc.), that are fundamental for the construction of synthesis and analysis. In the case of the research carried out, the option to use specific software of qualitative analysis was important in the deepening of the analyses carried out (Amado et al., 2017) (Costa \& Amado, 2018).

\section{Results and Discussion}

Since it is not possible to present all the results in this article, it was chosen, as already mentioned, to present the analysis performed to the Text 2: Presentation of the Happiness and Positivity Programme ("Mohammed reviews UAE Programme for Happiness and Positivity - Emirates24|7," 2016)

Regarding the presentation of the National Happiness and Positivity Programme. The analysis of the selected publication highlights several concepts and objectives, such as: positivity, 
happiness, measurement and evaluation, government policies, connection to the private sector, sharing ideas, investing in science and culture and three main objectives.

From the work done using the software, it was possible to verify that the reference to "positivity" appears several times throughout the text as a complement to happiness, as can be seen from the following excerpts of the text:

- "The National Happiness Programme should contribute to the building of a positive and happy community" [Ref. 1]

- "(...) promoting positivity as a fundamental value in the local community" [Ref. 2]

- "Promotion of values of positivity and happiness as a way of life..." [Ref. 3]

- "(...) create a positive environment for all government officials and instil positive values in all ministries and government entities." [Ref. 4]

In this context, 'positivity' can be related as a synonym of optimism and willingness to consider the good side of everything, even in adverse conditions (the same meaning presented in the dictionary).

Throughout the ages there have been several thinkers who related optimism to positivity and based on these opinions the importance of optimism and motivation in the development of communities and countries can be inferred. Mahatma Gandhi, for example, argues that if societies want to progress, they should not repeat history, but make a new story (Jordis, 2017). In turn, the Dalai Lama argues that cultivating positive mental states such as generosity and compassion definitely leads to better mental health and happiness (Lama, Tutu, \& Abram, 2016). Machado de Assis, in turn, says that there are people who cry because they know that roses have thorns while others smile because they know that thorns have roses (Assis, n.d.).

By focusing on motivation and positivity in the logic of work, one can also understand its importance over time; the Philosopher and contemporary of Jesus Christ, Confucius, 2000 years ago affirmed that if people chose the jobs they liked, they would not have to work a single day in their lives (Confúcio, 2013).

The analysis allowed, regarding the word happiness, for it to begin to be linked to Positivity:

- "Promotion of values of positivity and happiness as a way of life in the community of the United Arab Emirates." [Ref. 1]

In addition, it is inferred that in the framework of the Ministry of Happiness, happiness, instead of a theoretical and isolated concept, appears as a structure of conscious life:

- "(..) a lifestyle in the United Arab Emirates. " [Ref. 2]

- "Our goal is to make happiness a way of life in the UAE community, as well as the noble purpose and ultimate goal of the government." [Ref. 3]

- "The goal is to make happiness a way of life in the community." [Ref. 4]

On the other hand, as has already been verified in the analysis of other texts that are not presented in this article, there are again references to measurement and evaluation of the results: 
- "The PM has recognised the need to accurately measure happiness among community members." [Ref. 1]

- "(..) development of innovative benchmarks and mechanisms for measuring happiness in the community." [Ref. 2]

Regarding government policies, it is understood that the communication does not fail to mention that the Happiness issue will be very present in the work of the Government and will be supported by government policies, as one can draw from several phrases throughout the text:

"Policies, programmes, services and the work environment in ministries, he emphasised, should focus on happiness." [Ref. 1]

"Our purpose is... as well as the noble purpose and ultimate goal of the government." [Ref. 2]

- (...) happiness in policies, programmes and services of all governmental entities and the work environment. " [Ref. 3]

- "Our policies contribute to building a happy community." [Ref. 4]

- "Government policies, programmes and services should contribute to building a positive and happy community." [Ref. 5]

- "Sheikh Mohammed said that the government's main task is to ensure that conditions are conducive to providing..." [Ref. 6]

- "(..) aims to align government policies, programmes and legislation to provide happiness and positivity in the community." [Ref. 7]

The analysis also allows for the verification that the Government communication is not confined to the public sector. The issue of Happiness and Positivity will be boosted by the Government, considering the involvement of the business community in a close connection between the Government and the private sector as fundamental, as can be seen from the following text extracts:

- "(...) aims to align government policies, programmes and legislation to provide happiness and positivity in the community and to encourage the public and private sectors to launch, recommend and take initiatives in this regard. " [Ref. 1]

- "... improve co-ordination with the private sector to achieve this goal." [Ref. 2]

At the same time, it can be seen that the government does not intend to have exclusivity in the intervention. That is why it refers to the need to share ideas among the whole community:

- "Sheikh Mohammed also emphasised the importance of receiving and exchanging ideas, proposals and opinions of individuals and corporations on happiness and positivity." [Ref. 1]

With regard to investment, especially in science and culture, the government does not rule out its responsibilities, and as can be seen from the text, it lays down several initiatives:

- "The plan will include initiatives for the publication of scientific and cultural content and books on happiness to encourage reading in the area of awareness of the importance of positivity and happiness as an integrated way of life" [Ref. 1] 
From the content analysis carried out on this text it is possible to conclude that the three main objectives of the government are:

- "Promotion of values of positivity and happiness as a way of life in the community of the United Arab Emirates." [Ref. 1]

- "happiness in policies, programmes and services of all government entities and the work environment. "[Ref. 2]

- "(..) development of innovative benchmarks and mechanisms for measuring happiness in the community." [Ref. 3]

In summary, a major focus is seen in government policies. Positivity appears with a focus that is very close and complementary of happiness. Of note is 'happiness as a way of life' and the involvement of the private sector in the National Happiness and Positivity Programme. In addition, it was possible to verify that the word 'community' also has a strong presence as can be seen in the following 'cloud' of words obtained (Figure 2).

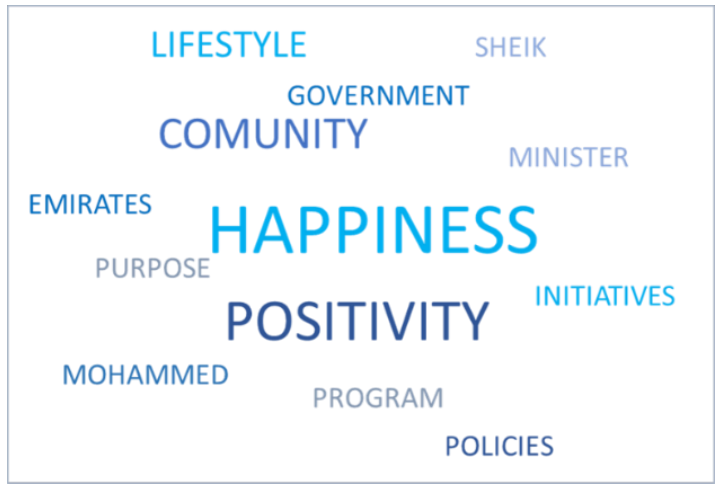

\begin{tabular}{|l|r|}
\hline HAPINESS & 22 \\
POSITIVITY & 14 \\
COMUNITY & 11 \\
LIFESTYLE & 10 \\
GOVERNMENT & 8 \\
EMIRATES & 7 \\
MOHAMMED & 7 \\
INITIATIVES & 6 \\
POLICIES & 6 \\
PROGRAM & 5 \\
PURPOSE & 5 \\
SHEIK & 4 \\
MINISTER & 4 \\
\hline
\end{tabular}

Figure 2 - Frequent words

In addition to the notes to the above paragraph, it should also be mentioned that, in the case of a government programme, it is considered natural that both the word government and the name and reference to the head of this government appear prominently in the 'cloud' of words.

The study of this text is in line with the principles recommended by Torquato regarding the role of government communication as a means of informing citizens about what happens within the government, and that is why it is an instrument that allows them to learn about government actions (Torquato, 1985). The government believes that happy employees are contagious to clients, and also wants private companies to work to make clients happy. To this end, it emphasises in its communication and, in this case, through the dissemination of the National Happiness Programme, the concepts and actions that will lead to the implementation of this programme.

The analysis allowed for the verification that there is uniformity in the content of the National Happiness Programme, whose 3 main areas are: 1) Inclusion of happiness in the policies, programmes and services of all government agencies as well as in the work environment; 2) Consolidation of values of positivity and happiness as a way of life in the community of the 
United Arab Emirates; 3) Development of tools and indices to measure levels of happiness, and the news that makes the same programme known.

Thus, it can be inferred that government communication is carefully elaborated and follows the organisation presented by some experts. As indicated by Kunsch (2003), government communication is not an easy process, and the government must make an effort to improve its communication, making it understandable and accessible to all.

The research carried out allows us to conclude, in our view, that the above mentioned principles of theoretical application suggested by Torquato (2002) are fulfilled in their entirety, almost in compliance with a previously established script.

\section{Discussions and Implications}

The analysis made it possible to verify the discursive congruence of the text analysed and the description of the National Happiness Programme itself, namely through the three main areas of this Programme. It is also worth mentioning the creation of a 'scorecard' as a practical instrument for measuring and evaluating the results of government policies foreseen in the PNF. There was also the emphasis given to happiness as a lifestyle.

The research allowed for the observation of which are the most used concepts in government communication of the Ministry of Happiness: Positivity, Happiness and Community. It allowed for the conclusion that the government set up a concrete programme to achieve the outlined policy measures and that it intends to communicate not only through the submission of tenders in the media, but also by implementing or carrying out various actions.

The results allow for the inference that there is a great focus on government policies and that the Government intends to get the public and private sector involved in the National Happiness and Positivity Programme

Transposing the results gathered for a broader view on the communication of the Ministry of Happiness, it is possible to highlight three main elements: 1) that it is based on the theoretical principles of government communication; 2) that the strategies are defined with specialised advice with the support of international reference organisations; 3) that it systematically refers to social media and social networks (D. Ribeiro et al., 2020).

This study, as well as the studies carried out in the scope of the broader research that has been developed on this subject, allows for the conclusion that, effectively, government communication has a strong influence on Happiness, it also being possible to conclude that the communication can contribute greatly to the success of the policies defined by the government.

The study can be regarded as a contribution to governments worldwide and other institutions on the simplicity of implementing a happiness and positivity programme and on how to communicate it to the citizens.

For the authors, happiness policies together with a well-defined communication programme can also be developed implemented by other institutions, where academy is included introducing the concept of theory 'in action' as far as sustainable happiness and positivity programs are concerned. Further studies on the gap between aimed happiness and real happiness levels in the academic community are strongly recommended. 


\section{References}

[1] Amado, J., Costa, A. P., \& Crusoé, N. (2017). A Técnica de Análise de Conteúdo. In Manual de Investigação Qualitativa em Educação.

[2] Assis, M. de. (n.d.). Obra Completa. Retrieved from http://machado.mec.gov.br/obracompleta-lista

[3] Bardin, L. (2009). Análise de conteúdo (3rd ed.). Lisboa: Edições 70.

[4] Brandão, E. P. (2009). Conceito De Comunicação Pública. Comunicação: Estado, Mercado, Sociedade e Interesse Público, 1-21.

[5] Confúcio. (2013). As lições do Mestre (Traduzido por André Bueno). Brasil: Geração editorial.

[6] Costa, A. P., \& Amado, J. (2018). Content Analysis Supported by Software. Aveiro: Ludomédia. $\quad$ Retrieved from https://www.ludomedia.pt/en/prod_details.php?id=172\&catId=13\&offset $=0$

[7] Costa, A. P., de Souza, F. N., Moreira, A., \& de Souza, D. N. (2018). webQDA 2.0 Versus webQDA 3.0: A Comparative Study About Usability of Qualitative Data Analysis Software (pp. 229-240). https://doi.org/10.1007/978-3-319-58965-7_16

[8] Costa, A. P., Linhares, R., \& de Souza, F. N. (2014). Possibilidades de Análise Qualitativa no webQDA e colaboração entre pesquisadores em educação em comunicação. In R. Linhares, S. de L. Ferreira, \& F. T. Borges (Eds.), Infoinclusão e as possibilidades de ensinar e aprender (pp. 205-215). Universidade Tiradentes, Aracaju - Brasil: Editora da Universidade Federal da Bahia.

[9] Costa, A. P., Reis, L. P., \& de Souza, F. N. (2014). Investigação Qualitativa para Sistemas e Tecnologias de Informação. RISTI - Revista Ibérica de Sistemas e Tecnologias de Informação, (E2). https://doi.org/10.17013/risti.e2.ix-xii

[10] Fredrickson, B. (2001). The Role of Positive Emotions in Positive Psychology. The Broaden-and-Build Theory of Positive Emotions. Am Psychol.

[11] Jordis, C. (2017). Gandhi. Biografia. Traduzido por Paulo Neves. Brasil: L\&PM Pocket.

[12] Kanozia, R. (2016). Environment communication for sustainable development in Punjab, India. Journal of Content, Community and Communication, 4, 41-49.

[13] Kringelbach, M. L., \& Berridge, K. C. (2010). The Neuroscience of Happiness and Pleasure. New YorK: Soc. Res.

[14] Krippendorff, K. (1990). Metodología de análisis de contenido : teoría y práctica. Ediciones Paidós.

[15] Kunsch, M. (2003). Planejamento de relações públicas na comunicação integrada. São Paulo: Summus.

[16] Lama, D., Tutu, D., \& Abram, D. C. (2016). The Book of Joy: Lasting Happiness in a Changing World. New York.: Avery.

[17] Lyubomirsky, S., Sheldon, K. M., \& Schkade, D. (2005). Pursuing Happiness: The Architecture of Sustainable Change. University of California. Riverside.

[18] Mohammed reviews UAE Programme for Happiness and Positivity - Emirates24|7. (2016). Retrieved May 28, 2016, from https://www.emirates247.com/news/government/mohammed-reviews-uaeprogramme-for-happiness-and-positivity-2016-03-07-1.623503

[19] Pina, A. R. B., Neri de Souza, F., \& Leão, M. C. (2013). Investigación educativa a partir de la informacion latente en internet. Revista Eletrônica de Educação, 7(2), 301-316. 
[20] Ribeiro, D., Costa, A. P., \& Remondes, J. (2020). Government Communication - The Dubai and United Arab Emirates Ministry of Happiness (pp. 226-238). https://doi.org/10.1007/978-3-030-31787-4_19

[21] Ribeiro, D. , Laranjeira, E., \& Remondes, J. (2019). Creation of the "Happiness 360o" Model: Qualitative Analysis from Survey Responses. Fronteiras: Journal of Social, Technological and Environmental Science, 8(1), 93-112. https://doi.org/10.21664/2238-8869.2019v8i1.p93-112

[22] Ribeiro, D. , Remondes, J., \& Costa, A. P. (2017). Comunicação do Ministério da Felicidade dos Emirados Árabes Unidos. Análise de dados qualitativos disponíveis na Internet. In António Pedro Costa, S. Tuzzo, \& C. Brandão (Eds.), Atas do 60 Congresso Ibero-Americano em Investigação Qualitativa (Volume 3 - Investigação Qualitativa em Ciências Sociais) (pp. 686-691). Ludomedia. Retrieved from https://proceedings.ciaiq.org/index.php/ciaiq2017/article/view/1443

[23] Ribeiro, D.., Remondes, J., \& Costa, A. P. (2019a). A Comunicação do Ministério da Felicidade do Dubai e Emirados Árabes Unidos no ano 2016. In comunicação, Redes Sociais e a Produção Artistica (Vol. 1, p. 53 a 74). Atena Editora. https://doi.org/10.22533/at.ed.932191905

[24] Ribeiro, D., Remondes, J., \& Costa, A. P. (2019b). Comunicação governamental: o exemplo do ministério da felicidade dos Emirados Árabes Unidos. Ámbitos. Revista Internacional de Comunicación, 44(44), 54-72. https://doi.org/10.12795/Ambitos.2019.i44.04

[25] Ribeiro, D., Remondes, J., \& Costa, A. P. (2019c). Estudo de caso sobre a comunicação governamental relativa à criação do Ministério da Felicidade do Dubai e Emirados Árabes unidos. In Ciências Sociais Aplicadas: Entendendo as Necessidades da Sociedade 2 (Vol. 2, pp. 29-44). Brasil: Atena Editora. https://doi.org/10.22533/at.ed.2451925064

[26] Seligman, M. (2011). Authentic Happiness: Using the New Positive Psychology. London. Boston: Nicholas Brealey Publishing.

[27] Tkach, C., \& Lyubomirsky, S. (2006). How Do People Pursue Happiness?: Relating Personality, Happiness-Increasing Strategies, and Well-Being. Journal of Happiness Studies.

[28] Torquato, G. (1985). Marketing Político E Governamental um roteiro para campanhas políticas e estratégias de comunicação. S. Paulo: Summus.

[29] Torquato, G. (2002). Tratado de comunicação Organizacional e Politica. S. Paulo: Pioneira Thomson Learning. 